\title{
Escravos na povoação de Santa Cruz na segunda metade do século XIX
}

\author{
Guilherme Würdig Spindler ${ }^{1}$ \\ Roberto Radünz ${ }^{2}$ \\ Olgário Paulo Vogt ${ }^{3}$
}

\begin{abstract}
RESUMO
O presente artigo tem como objetivo evidenciar a presença de escravos na região da Colônia de Santa Cruz (atual município de Santa Cruz do Sul) durante a segunda metade do século XIX. Partimos do processo-crime $\mathrm{N}^{\circ}$ 4776, de 1876, no qual o pardo Lucas, jornaleiro, escravo de Adão Schirmer, foi acusado como autor do homicídio da preta Maria, escrava de Jacob Graeff. Maria, quitandeira, residia na Vila de Santa Cruz. Também utilizamos como fontes os registros da Paróquia de Santa Cruz referentes aos batismos e óbitos de escravos e libertos entre os anos de 1861 e 1886. Concluímos que, apesar de existirem leis provinciais e imperiais que proibiam aos colonos que possuíssem cativos, não se sustenta a tese de que não haviam escravos na região em estudo. Pela documentação consultada foi possível concluir que circularam escravos pela povoação, pela própria Colônia de Santa Cruz e em suas adjacências. Esses escravos não pertenciam a colonos, mas certamente a escravidão não foi estranha aos imigrantes que se estabeleceram pela região. A presente comunicação faz parte do projeto "Senhores, escravos e colonos: redes, conflitos e negociações no Vale do Rio Pardo".
\end{abstract}

PALAVRAS-CHAVE: Escravidão. Colônia de Santa Cruz. Imigração.

\begin{abstract}
The present article has the objective of evidencing the presence of slaves in the region of the Colônia de Santa Cruz (known today as Santa Cruz do Sul) during the second half of the XIX century. Starting from the crime-process $\mathrm{N}^{\circ} 4776$, of 1876, in wich the brown Lucas, daysman, slave of Adão Schirmer, was accused of the murderer of the black Maria, slave of Jacob Graeff. Maria, greengrocer, lived in the Vila de Santa Cruz. We also utilized as source the registers of the Paróquia de Santa Cruz referents of the baptisms and deaths of slaves and freed between the years of 1861 and 1886. Concluding that, besides the existence of provincial and imperial laws that prohibited the settlers from having slaves, it isn't endurable the teases that wasn't slaves living in the studied region. From the consulted documentation was possible to conclude that was slaves among the township, trough the Colônia de Santa Cruz itself and it's surroundings. These slaves didn't belonged to the settlers, but certainly the slavery wasn't strange to the immigrants that settled although the region. The present communication does part of the project "Senhores, escravos e colonos: redes, conflitos e negociações no Vale do Rio Pardo".
\end{abstract}

KEYWORDS: Slavery. Colônia de Santa Cruz. Immigration.

\footnotetext{
${ }^{1}$ Aluno do Curso de História da Universidade de Santa Cruz do Sul - UNISC.

${ }^{2}$ Professor do Departamento de História e Geografia na Universidade de Santa Cruz do Sul e Professor na Universidade de Caxias do Sul - UCS.

${ }^{3}$ Professor do Departamento de História e Geografia na Universidade de Santa Cruz do Sul.

<olgario@unisc.br>
} 


\section{INTRODUÇÃO}

Esta pesquisa teve início quando travamos contato com um processo crime do ano de 1876, encontrado no acervo do Arquivo Público do Estado do Rio Grande do Sul. ${ }^{4}$ Nele, o pardo Lucas, cativo de Adão Schirmer, era acusado de ter assassinado barbaramente a preta Maria, escrava de Jacob Graeff. Lucas no final foi absolvido por falta de provas. Inicialmente, o que mais chamou a atenção nesse processo foi o fato de os sobrenomes dos amos de ambos os escravos serem de origem germânica. Analisando mais detidamente o processo, percebeuse que o fato apontava para possíveis relações entre colonos alemães e escravos. Essas relações haviam passado despercebidas pela historiografia regional.

O objetivo desse artigo é investigar a presença de escravos no território da Colônia de Santa Cruz (atual município de Santa Cruz do Sul) na segunda metade do século XIX. Apesar dos governos do Império e da Província de São Pedro proibirem legalmente a posse de escravos por parte de colonos imigrantes, ao consultar a documentação disponível, foi possível constatar que havia pelo menos alguns escravos na povoação, no entorno colonial e mesmo dentro da colônia oficial. A partir dessa constatação surgiram inúmeros questionamentos sobre os escravos existentes na Freguesia e depois Vila de Santa Cruz. Em que quantidade realmente eles eram? Quem os possuía? Onde estavam distribuídos? Como viviam? Quais eram suas ocupações? Como se relacionavam? Como foi a interação entre esses escravos e os colonos alemães? O presente artigo, obviamente, não dará conta de responder a todos esses questionamentos. Para tanto seria necessário realizar inúmeras novas pesquisas e ter contato com fontes documentais que, possivelmente, sequer existam. Mas foi a partir dessas perguntas que conduzimos nossas reflexões. Esperamos ao menos dar algumas pistas sobre as questões levantadas.

Os trabalhadores cativos foram praticamente invisibilizados pela historiografia que tratou sobre a colonização e a formação social e econômica dos municípios da região. Partimos do pressuposto que Santa Cruz não poderia ser uma ilha fora do contexto da escravidão. Durante todo o Brasil Imperial, o trabalho escravo foi o grande motor que movimentou a economia brasileira e gaúcha. Os escravos africanos, de alguma forma, estiveram presentes na vida de quase todos os brasileiros e sul-rio-grandenses, ai incluindo os imigrantes.

Passamos então a analisar outros documentos que pudessem dar informações sobre a presença de cativos na colônia e adjacências. Para tanto, utilizamos os registros da Paróquia de São João de Santa Cruz. Consultamos o Livro de Registro de Óbitos de Escravos entre os

\footnotetext{
${ }^{4}$ O processo pode ser localizado em APERS: Civil e Crime. 1876, N. 4776, M. 96, E. 50.
} 
anos de 1861-1882; o Livro de Registro de Batismos de Escravos existente entre os anos de 1863 e 1873; e o Livro de Batismos dos Libertos onde se encontram assentamentos relativos aos anos de 1872 até 1886. Essa documentação encontra-se na Cúria Metropolitana, em Porto Alegre. Além disso, foram analisados os inventários post-mortem de Guilherme Lewis, Felisberta Graeff e Henrique Jacob Graeff, Manoel Pedroso de Albuquerque e de Clara Frantz. Esses inventários encontram-se no Arquivo Público do Estado do Rio Grande do Sul (APERS). Utilizamos também alguns apontamentos feitos por João Martinho Buff, que foi diretor da Colônia de Santa Cruz nos seus primeiros anos de existência. Esses escritos encontram-se no Arquivo Histórico do Rio Grande do Sul (AHRS).

\section{A CONSTITUIÇÃO DA COLÔNIA SANTA CRUZ}

Em 1849 foi criada a colônia de Santa Cruz. Sua fundação está inserida na segunda fase da imigração alemã no Rio Grande do Sul (ROCHE, 1969). Ela foi organizada e administrada pelo governo provincial, a partir de um aparato legal que regrou a colonização e o acesso à terra no país: estamos nos referindo à lei número 514, de 28 de outubro de 1848, que concedia terras devolutas do Império às Províncias para a colonização; e à lei 601, de 18 de setembro de 1850, que modificou permanentemente o modelo de distribuição e apropriação da terra, que passou a ser comprada e não mais concedida.

Vários são os motivos apontados para a emigração de alemães durante o século XIX. Os colonos que se fixaram no Brasil Meridional eram movidos pelo desejo de se tornarem proprietários de terras, já que abandonavam seu lugar de origem devido à pobreza, à fome, desemprego, guerra e razões políticas, todas consequências advindas do crescimento demográfico, da industrialização, da urbanização e da proletarização pela qual passavam muitas das nações europeias (ALVIN, 1998, p. 235).

Já para o governo central do Brasil, a imigração era uma oportunidade de branqueamento da população. Dois projetos distintos estavam previstos para esses colonos: nos locais dominados pela cafeicultura, o objetivo era sanar a escassez de força de trabalho; no caso do Rio Grande do Sul e de outras províncias, os imigrantes eram direcionados para a instalação de pequenas propriedades rurais nos vazios demográficos de terras devolutas, impróprias para a criação de gado e de grandes latifúndios, onde desenvolveram a agricultura de subsistência e, depois de estabelecidos, passaram a suprir os centros urbanos próximos de gêneros alimentícios básicos. 
Havia tanto colônias oficiais, criadas pelos governos imperial, provincial ou municipal, quanto colônias particulares. No caso dos empreendimentos particulares, como havia custos para a demarcação e medição dos lotes e para a abertura de picadas, certos empreendedores arcavam com esses custos iniciais e depois revendiam aos interessados. Muitas dessas colônias particulares surgiram nas adjacências dos empreendimentos oficiais, pois a instalação das colônias oficiais valorizava rapidamente os territórios dos arredores, tornando esse um investimento bastante vantajoso. Conforme Vogt, no caso da colônia de Santa Cruz:

De Linha Santa Cruz, a colonização se expandiu na direção de Rio Pardinho, Dona Josefa, Linha Andréas, Sinimbu, Vila Tereza e Ferraz. Uma vez ocupadas as terras devolutas da Colônia, áreas de particulares foram loteadas dando origem, dentre outras, a Rio Pardense, Faxinal de Dentro, Colônia Germânia (Candelária), Entre-Rios, Formosa, Trombudo, Pomerânia, Chaves, Linha João Alves, Cerro Alegre, São João da Serra, Pinheiral, Linha Nova e outras. (VOGT, 2006, p. 97)

Paralelamente à expansão da área colonial, surgiram os povoados de São João e de Vila Tereza que, respectivamente, deram origem às atuais cidades de Santa Cruz do Sul e de Vera Cruz. Os povoados eram criados para se constituir no centro econômico, religioso e político-administrativo de um território colonial. No caso do povoado que deu origem à Santa Cruz, este situava-se em terras desapropriadas da antiga sesmaria de João de Faria Rosa (MENEZES, 1913, p. 20). Estava, portanto, localizado fora da área colonial que se situava mais em direção Norte, distando alguns quilômetros dessa. As primeiras oito quadras de 132 metros de face foram medidas entre 1854/55 e estavam localizadas no entorno da atual Praça Getúlio Vargas (MARTIN, 1999, p. 25). Em 1857 teve início a construção da Capela de São João, que se localizava em frente da atual Catedral de São João Batista. A construção da capela, paga com recursos do governo provincial, foi arrematada por Guilherme Lewis e a obra só ficaria pronta em junho de 1863 (MARTIN, 1979, p. 128).

Santa Cruz foi elevada à condição de freguesia em 1859. Em 1878 tornou-se vila (município), emancipando-se de Rio Pardo. Parafraseando Moreira e Mugge (2014, p. 46), “a Vila não era um local inóspito e isolado, mas uma encruzilhada prenhe de contatos e experiências sociais e étnicas diversas.” Embora os autores nessa passagem estivessem se referindo particularmente a São Leopoldo, acreditamos que o povoado e a colônia de Santa Cruz tivessem, na segunda metade do século XIX, semelhante condição, pois constituía-se em um importante ponto de passagem e de contato entre Rio Pardo e os Campos de Cima da Serra. Já em 1856, sete anos após sua fundação, abrigava 1.451 pessoas (MARTIN, 1979, p. 109). Certamente muitas relações aconteciam em seu território de transição entre o Vale do Rio Jacuí e a Serra Geral. 
Monte Alverne (Figura 1) foi também uma colônia provincial, criada em 1859, em terras do município de Taquari. Nos seus arredores surgiram também uma série de colônias privadas, dentre os quais a da firma Pereira \& Cia, gerenciada por Carlos Trein Filho.

\section{Figura 1: Mapa da colônia de Monte Alverne e de outras colônias da circunvizinhança.}

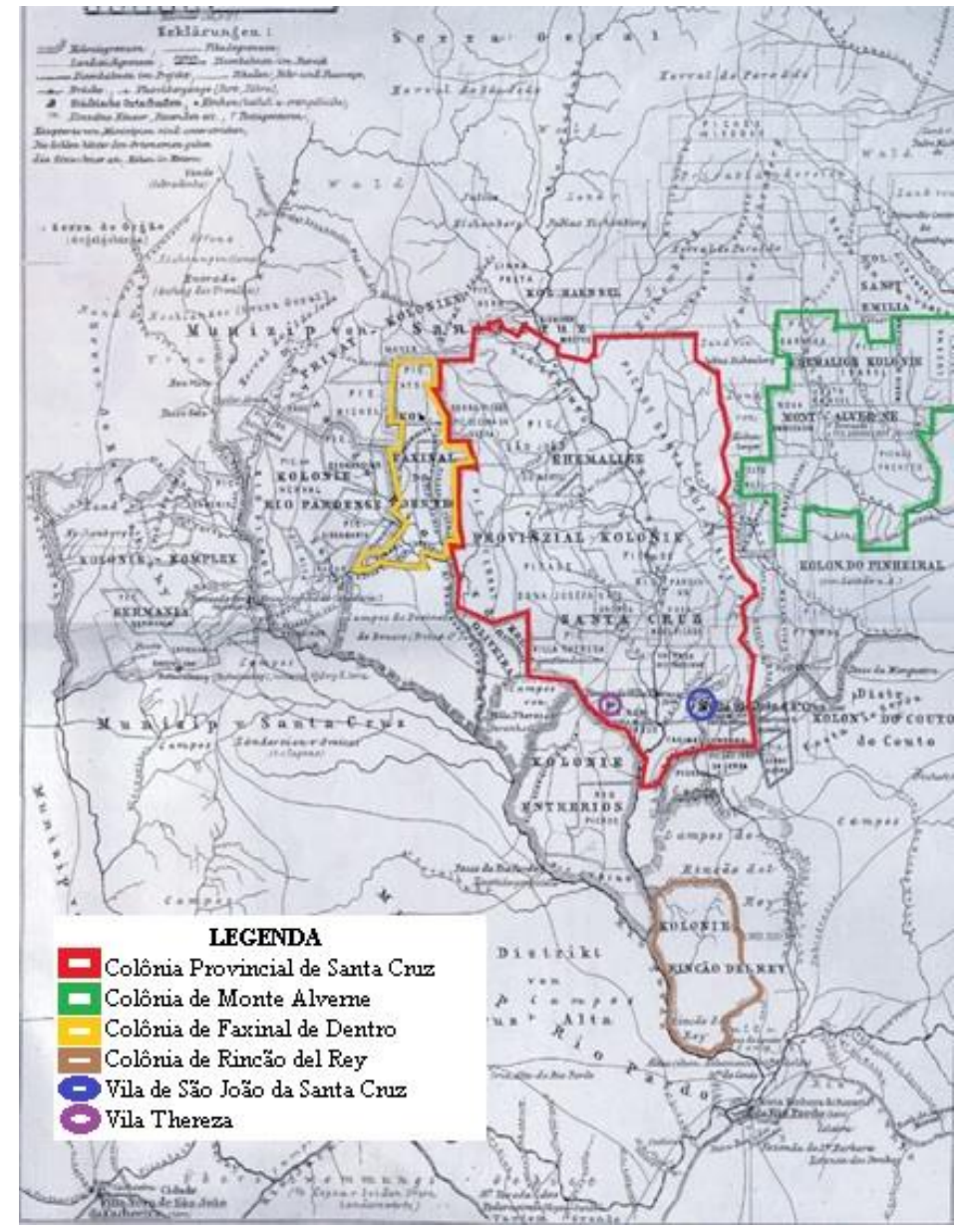

Fonte: Mapa adaptado pelos autores a partir do original de B. Kassenstein, de 1889, apud Vogt, 2006, p. 101.

\subsection{COLONOS ALEMÃES E ESCRAVIDÃO}

No livro "Histórias de escravos e senhores em uma área de imigração europeia", os autores indicam uma série de pesquisadores que já trabalharam com o tema escravidão e colonos. Dentre eles estão Magda Gans, Eliege Alves, Marcos Tramontini, Ricardo Charão e Vinicius de Oliveira (MOREIRA, MUGGE, 2014, p. 14). O que há de comum nos trabalhos desses historiadores é que todos eles demonstraram ter havido relações as mais diferentes entre colonos e cativos. Nesse sentido, as colônias de imigrantes não estavam deslocadas no tempo e no espaço, estando sujeitas a conviver com a presença do trabalhador escravo. Moreira e Mugge, nesse sentido, tecem importantes considerações: 


\begin{abstract}
Os imigrantes europeus - no nosso caso especificamente os alemães - que se deslocaram para o Brasil no século XIX, conheceram intimamente a escravidão negra. Muitos deles, inclusive, possuíram cativos, e os alugaram, os açoitaram, os venderam, os alforriaram. No caso do Rio Grande do Sul, os imigrantes alemães começaram a chegar em 1824 e foram instalados na Colônia Imperial de São Leopoldo, de onde se apraiaram pela província e para fora dela. Praticamente paralela à constituição de uma sociedade escravista nesta área de colonização europeia, forjou-se uma historiografia apologética que destacou esta imigração como propugnadora de novos valores morais e econômicos, quais sejam, a poupança, o amor, a família, a religiosidade, a regeneração do trabalho manual. (MOREIRA, MUGGE, 2014, p. 20-21)
\end{abstract}

Esse foi o caso de São Leopoldo. Mas cai como uma luva para o caso de Santa Cruz do Sul, pois até o momento poucos escritos evidenciaram a presença da escravidão no município. Para Moreira e Mugge (2014, p. 85), isso decorre de "uma historiografia comprometida com as identidades municipais e familiares embasadas em ancestralidades (principalmente germânicas)", que nega ou minimiza a presença histórica negra nestas zonas. Esse tipo de discurso sustenta que os imigrantes europeus eram portadores de visões valorizadoras do trabalho manual e que suas unidades produtivas seriam sustentadas apenas pela mão de obra familiar. Nesse sentido, Ganz enfatiza que:

Esta tese da nobilitação do trabalho pelos alemães [...] é tributária, penso, de noções
próprias de laboriosidade, cidadania e progresso que surgiram entre os teuto-
brasileiros ao longo da segunda metade do século XIX, em grande parte forjadas pelos
intelectuais teuto-brasileiros daquele período, e que se difundiram amplamente na co-
munidade teuta, tornando-se senso comum e influenciando grande parte da historio-
grafia da imigração do século XX. (GANZ, 2004, p. 98 apud MOREIRA, MUGGE,
2014, p. 16)

A presença de alemães e de seus descendentes não impediu que homens e mulheres possuíssem outros por meio do instituto da escravidão. No caso do Vale do Rio dos Sinos, de colonização anterior, essa afirmação foi ainda mais verdadeira. Naqueles primeiros anos da colonização alemã, não existia nenhuma lei que proibisse os imigrantes recém-chegados de adquirir escravos.

O primeiro aparato legal para regular a posse de cativos por parte de colonos apareceu na Lei 514, de 28 de outubro de 1848, do Império do Brasil, que concedia terras devolutas às Províncias com o objetivo de que essas promovessem a colonização. Consta no Artigo. $16^{\circ}$ dessa lei que:

A cada uma das Províncias do Império ficam concedidas no mesmo, ou em diferentes lugares de seu território, seis léguas em quadra de terras devolutas, as quais serão exclusivamente destinadas à colonização e não poderão ser roteadas por braços escravos. (IOTTI, 2001, p. 108).

Em 18 de outubro de 1850 entrou em vigor a Lei Provincial $n^{\circ}$. 183, que proibia a introdução de escravos em territórios das colônias. Segundo essa norma jurídica 
Art. $1^{\circ}$. É proibida a introdução de escravos no território marcado para a s colônias existentes, e para as que para o futuro se formarem na Província.

Art. $2^{\circ}$. Os escravos, que atualmente existem no territórios das colônias, serão matriculados pelo Diretor, ou seus Agentes, em livro próprio dentro de dois meses, depois da publicação dessa Lei, fazendo-se no mesmo livro nota dos que falecerem.

Art. $3^{\circ}$. Todas as pessoas, que forem viajar às colônias, ou residirem nelas temporariamente, poderão levar os escravos precisos para seu serviço doméstico, sendo obrigados a enviar ao Diretor ou seus Agentes, uma relação dos mesmos escravos e a reconduzi-los para fora das colônias, quando se retirarem.

Art. $4^{\circ}$. Os escravos que forem introduzidos nas colônias, em contravenção a essa Lei, serão expelidos por ordem do Diretor, pagas as despesas pelos donos dos mesmos escravos.

Art. $5^{\circ}$. As disposições acima referidas compreendem igualmente as colônias formadas por particulares. (IOTTI, 2001, p. 603-604).

A proibição de existência de trabalhadores cativos em territórios coloniais valia tanto para as colônias oficiais quanto para as particulares. No que diz respeito especificamente à Colônia de Santa Cruz, o governo provincial parece ter exercido certa vigilância para coibir que colonos alemães ali instalados adquirissem escravos.

Já a lei provincial $\mathrm{n}^{\circ} 304$, de 30 de novembro de 1854, que regulamentava o modo como seria feita a colonização no Rio Grande do Sul, estipulava:

Art. $8^{\circ}$ - Os colonos poderão cultivar suas terras por si mesmos, ou por meio de pessoas assalariadas: não poderão porém fazê-lo por meio de escravos seus ou alheios, nem possui-los nas terras das colônias sob qualquer pretexto que seja. (IOTTI, 2001, p. 611)

Nesse sentido, inicialmente os colonos, a exemplo do documento assinado por Christiano Pulver em 11 de outubro de 1850, subscreviam um Termo de Responsabilidade onde constava, entre outros, que:

= Sétima $=$ Declara que não admitirá em sua Colônia escrava ou escravo para o serviço, e se obriga a dispor logo de qualquer escravo que por qualquer motivo legal the vier a pertencer, ficando sujeito a ser-lhe apreendido o mesmo escravo, sendo encontrado na sua, ou em qualquer colônia, tirando para fora e vendido em outro lugar, e a deduzir-se as despesas destas diligências, sendo-lhe entregue o restante, seja muito ou seja pouco. (MARTIN, 1979, p. 44).

Foi com base nessa legislação que Martin (1979, p. 26), afirmou que "não havia escravos" em Santa Cruz. Porém, há de se observar que a proibição se aplicava apenas a imigrantes dentro de territórios coloniais. No entorno da Colônia de Santa Cruz existiam sesmarias e colônias particulares e também a povoação de São João de Santa Cruz. Além disso, como se destacou acima, na própria colônia provincial residiam pessoas que não eram consideradas colonos imigrantes e que foram proprietárias de escravos.

Em correspondência remetida pelo Presidente da Província à Câmara de Rio Pardo, o chefe do executivo questionou sobre a existência de escravos na colônia. Na resposta encami- 
nhada pelo Diretor da colônia, João Martinho Buff, em de 10 de fevereiro de 1856, foram arrolados dez escravos que vivam no Faxinal e três na Picada Rio Pardinho (MARTIN, 1979, p. 107).

Em 29 de outubro 1857, o Presidente da Província, Ângelo Moniz da Silva Ferraz, ordenou ao diretor Buff que lhe informasse se os 21 escravos - 13 do sexo masculino e 8 do feminino - anotados nos mapas da população da Colônia Santa Cruz fossem de propriedade dos colonos. Em respota, Buff esclareceu:

[...] tenho a honra levar ao conhecimento de V. Excia. que os ditos escravos pertencem as seguintes família. Aos herdeiros de Vasco José da Silveira estabelecidos em terras de sua propriedade, muito anterior à fundação da colônia; a Guilherme Lewis na forma dita, distando da Povoação 3/4 de légua, com quanto se acha atualmente residindo na dita povoação, por ser o (...) da edificação da respectiva Capela. Ao Capitão Antonio Ignacio da Silva que tem só duas escravas de serviço doméstico, único com colônia, na qual faz a plantação com braços livres, e a Evaristo Alves de Oliveira, em terras de sua propriedade, encravadas na Colônia. (AHRS - Colonização - 63 - Santa Cruz - 20/11/1857)

O próprio diretor e agrimensor da Colônia, João Martinho Buff, responsável pelos trabalhos de abertura de picadas, pela medição e distribuição de lotes coloniais possuiu escravos. De acordo com Moreira e Mugge (2014, pp. 40-41), em 1871, "ele passou alforria para a crioula Clemência, nascida em Rio Pardo”.

José Paulo Eckert, no artigo "Athe a completa extinção", a partir da documentação produzida pela Câmara de Rio Pardo, apresenta informações de diversos quilombos instalados pela Serra Geral. As autoridades consideravam muito perigosa essa região ainda que, além de escravos foragidos, abrigava também populações indígenas e fugitivos da lei, na fronteira da expansão agrária do século XIX (ECKERT, 2007, pp. 12-13). “" [...] a fuga de escravos parece ter sido prática rotineira e deu muito trabalho aos capitães do mato nomeados pela Câmara Municipal de Rio Pardo.” (VOGT, 2001, p. 99).

Em 1863, Carlos Schwerin, diretor da Colônia de Santa Cruz, encontrou, nos matos localizados ao norte das linhas Ferraz e São João, vestígios de um quilombo numeroso cuja destruição solicitava (CUNHA, 1988, p. 113).

Nos apontamentos coligidos em 1913 pelo secretário da Intendência do município, João Bittencourt de Menezes, a única referência indireta à escravidão que aparece ao longo das 328 páginas compiladas, foi a distribuição, no povoado de Santa Cruz, do terreno de número 6, na quadra M. Esse lote urbano foi concedido ao Capitão do Mato. Ao capitão do mato cabia a tarefa principal de recapturar os escravos fugidos e entregá-los aos seus senhores. A essa classe pertenciam, segundo Maestri (1993), homens pobres, libertos, negros livres e até mesmo trabalhadores escravizados. Os capitães do mato gozavam de pouquíssimo prestígio 
social, seja entre os cativos que tinham neles seus inimigos, seja na sociedade escravocrata. Menezes referiu-se de forma pejorativa a esse personagem

Essa entidade, que fazia parte da instituição de triste memória, era o preto Joaquim, por alcunha o Gaiola, que morava no Faxinal Velho. Gaiola costumava exibir uma medalha ou cousa semelhante, à guisa de patente do seu honroso posto (MENEZES, 1913, p. 26, grifo do autor).

O certo é que Santa Cruz fazia limite com diversas áreas com forte presença de trabalhadores cativos. E como não estava isolada, seus habitantes estavam acostumados com a presença da escravidão, normal no Brasil dessa época. Vogt, referindo-se à presença de escravos em Rio Pardo, afirma que:

Na região em estudo, os escravos eram encontrados tanto nos núcleos urbanos então existentes quanto no meio rural. Via de regra, eles chegavam ao Rio Grande do Sul por intermédio dos comerciantes lusitanos e de seus correspondentes. Nos povoados de Rio Pardo, Santo Amaro e Encruzilhada eram utilizados para a realização de serviços domésticos e ofícios diversos como carpinteiro, pedreiro, ferreiro, sapateiro e outros. No meio rural, eram empregados nos serviços domésticos e nos diversos trabalhos existentes nas fazendas de criação e plantação. Como é possível observar, apresentam parcela significativa da população na virada do século XVIII para o XIX. (VOGT, 2001, p. 94).

\section{PRSENÇA DE CATIVOS EM SANTA CRUZ}

No Censo Demográfico de 1872, realizado por ordem imperial, aparecem 291 escravos residentes na Paróquia de Santa Cruz. Destes, 151 eram homens e 140 mulheres. Certamente é um número bem expressivo.

Em 1861, teve inicio os registros no Livro de Óbitos de Escravos da Paróquia de Santa Cruz. Nesse livro encontramos o apontamento de 23 falecimentos até 1882. A partir de 1863, iniciaram os registros no Livro de Batismos de Escravos da Paróquia de Santa Cruz. Até 1873, foi feito nesse livro o assentamento de 31 batismos de filhos de escrava. Nesses registros consta o nome da mãe e o do senhor desta, dos padrinhos e madrinhas (que às vezes eram também cativos, mas geralmente eram pessoas próximas da família dos amos) e a localidade em que viviam. Esse último dado é geralmente pouco especificado. Na maior parte dos casos, consta apenas que o senhor e/ou os escravos eram moradores "desta Freguezia" ou que o batismo ocorreu "nesta Matriz de S. João Baptista".

Ainda há um terceiro livro com registros que vai de 1872 até 1886 . Nele estão inscritos o batismo dos ingênuos, isto é, os filhos de escravas nascidos após a Lei de 28 de setembro de 1871, que libertou o ventre das mesmas. Constam nesse livro de registros o nome de 132 crianças. Segundo o artigo $8^{\circ}\left(\S 5^{\circ}\right)$ da Lei de 1871 , os párocos eram obrigados e ter li- 
vros especiais para o registro do nascimento e óbitos dos filhos de escravas, nascidos desde a data desta lei.

A partir dos livros de batismos e óbitos de escravos e libertos, chegamos a um número total de 337 registros de escravos na Paróquia de Santa Cruz. Desses, 202 eram nascidos antes de 1871, e 135 eram libertos sob condição, mas ainda atrelados às relações escravistas de trabalho. As informações de todos esses personagens e seus respectivos senhores não poderão ser detalhados aqui, mas demonstram a presença regular da escravidão na região. Os dados apresentados a seguir, constituem uma síntese do cruzamento dos apontamentos encontrados nos livros da Paróquia de Santa Cruz acima mencionados.

O Capitão Joaquim José de Brito (que mais tarde tornou-se Tenente Coronel, e hoje dá nome a uma das principais ruas do centro da cidade) possuía pelo menos dez escravos: Liberata, que teve três filhos ingênuos, Trojano (1873), Octaviano (1876) e Honoria (1882); Anna e seu filho Galdino (1881); Benedicta, filha de Mateo e Rita, nascida em 1857 e falecida em 1880; Januario, que nasceu em 1873; Leopoldina, madrinha de Octaviano; Balduino, padrinho de Trojano, junto com Maria Bemvinda, escrava de Adão Schirmer.

Junto com ele, há outros senhores que estão registrados na documentação como residentes na Vila de Santa Cruz: Alexandrina Carolina de Almeida, senhora de Maria Joanna, mãe de Barbarino (falecido em 1882) e de Arnaldo (nascido em 1883); Matheo José Ferreira de Farias, senhor de Marianna, mãe de Hedviges (1882); Daniel Warendorf, comerciante natural da Alemanha e proprietário de pelo menos quatro escravos: Olimpia, mãe de Joaquim (1872) e Luiz (1873); Eva, mãe de Marianna, que morreu 6 dias após o nascimento, em 1881. Marianna Consta como “nascida nos Suburbios d'esta Villa de Santa Cruz".

\section{Figura 2: Registro de Batismo da preta Marianna, filha de Eva, escrava do Sr. Daniel}

\section{Warendorff.}

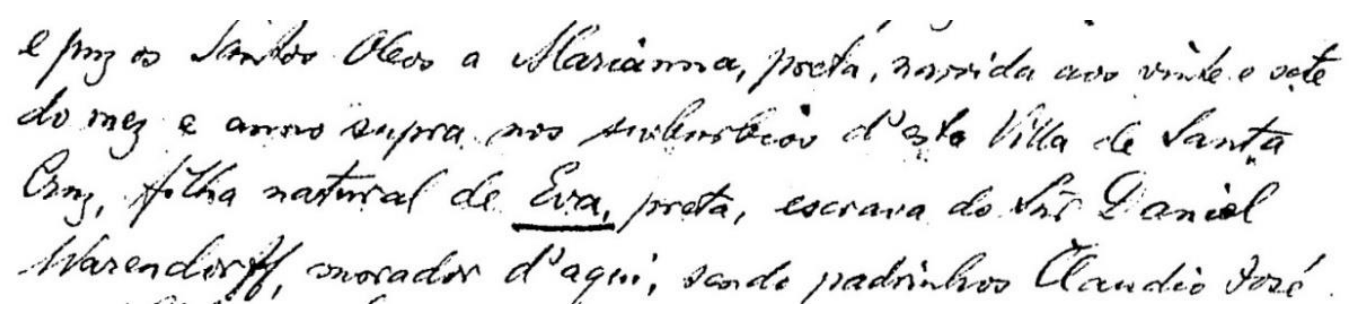

Fonte: Cúria Metropolitana, Livro de Registro de Batismos de Libertos (1872-1886).

Henrique Jacob Graeff, co-fundador da Colônia Germânia (hoje Candelária), possuía pelo menos quatro cativos. Apesar de ser morador da região do Couto, em Rio Pardo, sua escrava Maria, assassinada em 1876, residia na Vila de Santa Cruz, onde provavelmente era escrava de ganho, pois sua ocupação era quitandeira. Também lhe serviam Maria Roza, bati- 
zada em 1873, João e Polidermo, que aparecem em seu inventário (APERS, 1884, Inventário, N. 871, M. 38, E. 47).

Adão Schirmer tinha seis escravos. Lucas era jornaleiro em Santa Cruz e residia na Freguesia desde pelo menos 1874 (APERS: Civil e Crime. 1876, N. 4776, M. 96, E. 50). Foi ainda senhor de Maria (que por vezes aparece como Maria Bemvinda da Conceição) e seus filhos: Felirbius (que nasceu em 1875 e faleceu no ano seguinte, com 8 meses), Manoela Delfina (1877), Maria Idalina (1873) e Ernesto (1880).

Guilherme Lewis foi um dos primeiros a possuir terrenos na povoação (Menezes, 1913, pp. 23-24). Seu inventário (APERS, 1868, Inventário, N. 707, M. 31, E. 47), datado de 1868, registra a posse de três escravos: Gonçalo, crioulo, 55 anos, campeiro; Manoel, crioulo, 21 anos, cozinheiro; e Pedro, mulato, 21 anos, copeiro.

Villa Thereza (atual Vera Cruz) integrava a Colônia Provincial, e lá também residiam alguns senhores. Segundo os livros de registro de batismos e óbitos, José Paranhos da Silva era dono de sete cativos: Ernestina e sua filha Vicensia (1869); Emilia e seus quatro filhos, Rita (1871), Bibiano (1872), Rufino (1872) e Francisca (1876); José Furtado da Vieira possuía outros quatro escravos: Margarida, mãe de Silveiro (1862), Germano (1865) e Ricardo (1870). Pacifico Mariano de Oliveira era senhor de Firmina, que teve um filho, Antônio Francisco, em 1873. Antônio Luiz Pereira possuía a cativa Eva, mãe de Maria (1874). Carlos Wild era senhor de Dominga, que teve dois filhos, um enquanto era escrava deste, Bento (1881), e uma filha enquanto era escrava da D. Anna Vieira dos Santos. Francisca Gomes Sezyborowski morava em Rio Pardo, mas teve três escravos batizados em Villa Thereza, todos filhos de Maria Leopoldina da Conceição: Ernesto (1873), José (1878) e outro José (nascido em 1879 e falecido com 1 ano e 1 mês de idade, sepultado no cemitério de Villa Thereza). Ainda dentro da colônia oficial, há o caso de Onófrio de Oliveira Machado, dono de duas escravas na Picada de André (Dona Josefa): Firmina e sua filha Mariana Porciana (1877).

Os dados acima mostram que a propriedade escrava, dentro da colônia provincial, estava em mãos de proprietários com sobrenome, na sua maioria, português. Exceção se faz aos Wild, Sezyborowski, Schirmer, Graeff e Warendorff, que provavelmente não receberam lotes coloniais.

Quanto às colônias particulares, Bibiano de Oliveira Cortes possuía doze escravos em Faxinal de Dentro. Nicolau Scherer era proprietário de dois em Rincão del Rey. Antônio José Martim era dono de dois cativos em Herval do Paredão. Francisco Gomes da Fontoura possuía seis em Herval de São João. Manoel Soares Cezar possuía dois na Picada Facão. E Maria Fausta Lopes das Chagas tinha quatro escravos no Serro Alegre. 
A Tabela a seguir apresenta a quantidade de registros envolvendo escravos por década. O número não representa o número total de escravos, mas o de registros que conseguimos levantar. O número real de escravos existentes na paróquia certamente era bem maior. Aqui não estão contabilizadas as mães dos cativos, ou os padrinhos e madrinhas, mas apenas batismos, óbitos e aqueles encontrados em inventários.

Tabela 1: Número de registros de escravos nos Livros da Paróquia de Santa Cruz entre 1850 e 1880.

\begin{tabular}{llllll}
\hline Década & $\mathbf{1 8 5 0}$ & $\mathbf{1 8 6 0}$ & $\mathbf{1 8 7 0}$ & $\mathbf{1 8 8 0}$ & Total \\
Registros no Livro de Batismos de Escravos & - & 21 & 10 & - & 31 \\
Registros no Livro de Batismos de Ingênuos & - & - & 72 & 60 & 132 \\
Registros no Livro de Óbitos de Escravos & - & 8 & 11 & 4 & 23 \\
Outros registros & 21 & 3 & - & 2 & 26 \\
Total & 21 & 32 & 93 & 66 & 212 \\
\hline
\end{tabular}

Fonte: Cúria Metropolitana.

Os registros terminam em meados da década de 1880. Na ata da Câmara Municipal de Santa Cruz de 28 de fevereiro de 1885, consta que o vereador Abraão Tatsch solicitou ao Presidente da Câmara, Carlos Trein Filho, constar que, "[...] desde o dia 28 de janeiro de 1885, acha-se completamente extincta a escravidão n'este município.” (KAERCHER, 2004, p.31). Se a escravidão foi realmente extinta ou se ela foi camuflada em contratos de prestação de serviços, não tivemos como apurar.

\section{HOMICÍDIO DA ESCRAVA MARIA EM SANTA CRUZ}

Entre a meia noite do dia 7 e as duas horas da madrugada do dia 8 de março de 1876, ocorreu o bárbaro assassinato da preta Maria, quitandeira por ofício. A vítima, escrava de Jacob Graeff, residia na Freguesia de São João de Santa Cruz "na rua Rio Pardinho, no terreno sob o numero nove, na quadra U". O corpo da escrava, nu e sem sinal algum de vida, foi encontrado no chão, perto da porta de sua morada, pelas cinco horas da manhã, pelo marceneiro João Shuch, cuja morada ficava anexa à morada de Maria. Este imediatamente comunicou o caso ao subdelegado da Freguesia, Agostinho Antônio de Barros. O exame de corpo de delito, procedido pelos peritos José Krein (médico) e Henrique Eduardo Falk (pastor evangélico), apontou "que o cránio do cadaver se apresenta totalmente quebrado, estando a cabeça e cara 
ensanguentada, e não deixa a menor dúvida, que a morte immediata da preta foi produzida por este golpe mortal”. Lucas, solteiro, mulato, de 37 para 38 anos, natural de Rio Pardo, jornaleiro, escravo de Adão Schirmer, foi apontado como suspeito do crime.

Dentre as testemunhas inquiridas a respeito do homicídio encontrava-se Huggo Thompson, 35 anos, casado, natural do reino da Dinamarca, agrimensor, negociante e colono estabelecido na Freguesia. Declarou que no dia ou na noite em que foi morta a preta Maria não se achava na povoação. Chegando depois em casa, passados cerca de oito dias, dissera-lhe um de seus peões que o mulato Lucas queria cinco mil réis emprestados, cuja quantia não recebeu por dizer ele depoente, que não tinha dinheiro em casa. Disse também que o mesmo Lucas se oferecera para trabalhar por muito menos dinheiro do que qualquer outro trabalhador. Declarou mais que ele pessoalmente não sabe nada mais da morte da preta Maria, mas sabe e que é voz publica que o mulato Lucas é o autor da morte da preta Maria.

Felipe Spengler, 50 anos, carroceiro, casado, natural do Império Alemão, estabelecido na freguesia, ao ser inquirido sobre o que sabia a respeito do assassinato da dita preta Maria, respondeu o seguinte: que o mulato Lucas, escravo de Adão Schirmer, na tarde antes da morte da escrava Maria, retirara-se da casa dele depoente a cavalo, levando consigo todos os seus trastes, dentre os quais uma espingarda, uma mala e um poncho. De madrugada, pelas duas horas pouco mais ou menos, ouvindo o barulho dos cães no seu pátio, levantou-se e viu chegar o mulato Lucas. Ao meio dia deste mesmo dia, chegando os filhos do depoente da escola, contaram os mesmos que na noite anterior tinham matado a preta Maria. Lucas, que se achava presente, ouvindo essa conversa, teria exclamado: "Agora hão de dizer que fui eu que matei, por ter hido ao Faxinal a noite passada!"

Disse ainda o depoente que a sua mulher lhe pedira para despachar o mulato Lucas pelo motivo de o achar muito mudado e de ter medo dele. Falou ainda que no dia 9 pagou as contas do jornal de Lucas e que o filho do depoente observara que Lucas junto este dinheiro com outro que tinha na algibeira. Isso lhe pareceu estranho porque o filho do senhor do mulato Lucas tinha declarado a ele, filho do depoente, que o mesmo mulato no dia antes da morte da preta Maria não tinha dinheiro algum. Inquirido posteriormente pelo promotor público sobre a origem desse dinheiro, redarguiu que o tinha ganho do pastor Falk por serviços feitos em sua horta.

Outra testemunha foi Valentim Kolberg, 42 anos, casado, natural da Prússia, estabelecido na Freguesia. A testemunha contou que na noite do crime achavam-se em sua casa, reunidos, jogando, Gaspar Adão Schirmer, Manoel Pereira Jardim, Florentino de tal, Felicio Aralha e o mulato Lucas, escravo de Adão Schirmer. Que pela meia noite mais ou menos, todos 
se retiraram conjuntamente do local. Perguntado pelo promotor sobre a distância de sua casa até a que ocorreu o assassinato e da sua casa até a Spengler, respondeu: "Que calcula ser a distancia entre a sua casa e a de Spengler de meia legua, e que de sua casa a casa da assassinada haverá mais ou menos duzentos passos." Sem conseguir robustecer as provas, o promotor encaminhou o caso ao Juiz para sobre o assunto resolver o que julgasse de justiça. Analisando os autos, o Juiz considerou improcedente a denúncia.

\section{CONSIDERAÇÕES FINAIS}

Não se sustenta a tese de que não existiam escravos em Santa Cruz. Pelos registros apresentados, foram encontrados trabalhadores cativos na povoação, na própria Colônia de Santa Cruz e nas suas adjacências. Os escravos existentes dentro da colônia não eram de imigrantes. Conforme demonstra a documentação existente no AHRS, além dos imigrantes, houve gente que recebeu lotes coloniais, dentro da colônia oficial, a título de recompensa por serviços prestados ao Império e/ou à Província.

Dentro do território da colônia, não foi identificado nenhum colono que efetivamente fosse proprietário de escravos. No entanto, houve alguns donos de cativos com sobrenomes de origem germânica que residiam em áreas próximas à Colônia de Santa Cruz. Esses, possivelmente, deveriam ter adquirido os cativos no período anterior ao da vigência das leis que coibiam a utilização da força de trabalho escrava em áreas coloniais.

Para os colonos de Santa Cruz a existência do instituto da escravidão parece não ter sido coisa completamente estranha. Embora a pesquisa não tenha detectado, tudo leva a crer que deviam existir relações entre colonos e escravos. Pelo processo crime descrito, parece que o pardo Lucas circulava com alguma desenvoltura pela região montado em seu cavalo e munido de espingarda. Podia, inclusive, dedicar-se à jogatina sentando ao lado de homens livres, de origem lusa ou germânica. Lucas era jornaleiro e Maria, quitandeira. Tratavam-se, certamente, de negros de ganho. Vendiam seus serviços ou produtos pagando ao seu dono uma quantia fixa - o jornal - ou retendo um percentual do recebido. Se eventualmente prestaram serviços a colonos, esses os contratavam ao arrepio da Lei 304, de 1854. 


\section{REFERÊNCIAS}

ALVIN, Z. Imigrantes: a vida privada dos pobres no campo. In: Sevcenko, Nicolau (Org.). História da Vida Privada no Brasil. São Paulo: Cia das Letras, 1998.

CUNHA, J. L. da. Os colonos alemães de Santa Cruz e a fumicultura. Santa Cruz do Sul; Rio Grande do Sul, 1849 - 1881. Dissertação de Mestrado. Curitiba: UFPR, 1988. p. 113.

ECKERT, J. P. "Athe a completa extinção" - Quilombos em regiões florestais e a luta por liberdade no extremo sul do Brasil (Rio Pardo- séc. XIX). $3^{\circ}$ Encontro Escravidão e Liberdade no Brasil Meridional. Universidade Federal de Santa Catarina, 2007.

GANS, M. R. Presença teuta em Porto Alegre no século XIX (1850-1889). Porto Alegre: Editora da UFRGS/ANPUH/RS, 2004.

IOTTI, L. H., org. Imigração e colonização: legislação de 1747 a 1915. Porto Alegre: Assembléia Legislativa do Estado do RS. - Caxias do Sul: EDUCS, 2001. 864 p.

KAERCHER, N. J. Registros históricos de Santa Cruz do Sul: Câmara Municipal. Santa Cruz do Sul: Artexto, 2004.

MAESTRI, M. O escravo gaúcho: resistência e trabalho. Porto Alegre: Ed. da UFRGS, 1993. $87 \mathrm{p}$.

MARTIN, H. E. Recortes do passado de Santa Cruz. Organizado e atualizado por Olgário Paulo Vogt e Ana Carla Wünsch. Santa Cruz do Sul: Edunisc, 1999. 150p.

MARTIN, H. E. Santa Cruz do Sul: de colônia a freguesia 1849-1859. Santa Cruz do Sul: Associação Pró-Ensino em Santa Cruz do Sul, 1979. 139 p. (Coleção História de Santa Cruz do Sul; 2)

MENEZES, J. B. de. Município de Santa Cruz do Sul. 2. ed. / texto transcrito em ortografia atualizada por Arthur Rabuske. Santa Cruz do Sul: EDUNISC, 2005. 304p.

MOREIRA, P. R. S.; MUGGE, M. H. Histórias de escravos e senhores em uma região de imigração europeia. 2. ed. São Leopoldo: Oikos, 2014. 136p.

ROCHE, J. A colonização alemã e o Rio Grande do Sul. Porto Alegre: Globo, 1969. 799p.

VOGT, O. P. A colonização alemã no Rio Grande do Sul e o capital social. 2006. 435 f. Tese (Programa de Pós-Graduação em Desenvolvimento Regional - Mestrado e Doutorado) - Universidade de Santa Cruz do Sul, Santa Cruz do Sul, 2006. 
VOGT, O. P.; SILVEIRA, R. L. L. (Organizadores). Vale do Rio Pardo: (re)conhecendo a região. Santa Cruz do Sul: EDUNICS, 2001. 395 p.

\section{Como citar este documento:}

SPINDLER, Guilherme Würdig; RADÜNZ, Roberto; VOGT, Olgário Paulo. ESCRAVOS NA POVOAÇÃO DE SANTA CRUZ NA SEGUNDA METADE DO SÉCULO XIX. Revista Jovens Pesquisadores, Santa Cruz do Sul, v. 6, n. 2, nov. 2016. ISSN 2237-048X. Disponível em: <https://online.unisc.br/seer/index.php/jovenspesquisadores/article/view/7386>. Acesso em: ... doi:http://dx.doi.org/10.17058/rjp.v6i2.7386. 